\title{
Linking nutritional regulation of Angpt/4, Gpihbp1, and Lmf1 to lipoprotein lipase activity in rodent adipose tissue
}

Olessia Kroupa ${ }^{1}$, Evelina Vorrsjö ${ }^{1}$, Rinke Stienstra ${ }^{2}$, Frits Mattijssen ${ }^{2}$, Stefan K Nilsson ${ }^{1,3}$, Sander Kersten², Gunilla Olivecrona ${ }^{1}$ and Thomas Olivecrona ${ }^{1 *}$

\begin{abstract}
Background: Lipoprotein lipase (LPL) hydrolyzes triglycerides in lipoproteins and makes fatty acids available for tissue metabolism. The activity of the enzyme is modulated in a tissue specific manner by interaction with other proteins. We have studied how feeding/fasting and some related perturbations affect the expression, in rat adipose tissue, of three such proteins, LMF1, an ER protein necessary for folding of LPL into its active dimeric form, the endogenous LPL inhibitor ANGPTL4, and GPIHBP1, that transfers LPL across the endothelium.

Results: The system underwent moderate circadian oscillations, for LPL in phase with food intake, for ANGPTL4 and GPIHBP1 in the opposite direction. Studies with cycloheximide showed that whereas LPL protein turns over rapidly, ANGPTL4 protein turns over more slowly. Studies with the transcription blocker Actinomycin D showed that transcripts for ANGPTL4 and GPIHBP1, but not LMF1 or LPL, turn over rapidly. When food was withdrawn the expression of ANGPTL4 and GPIHBP1 increased rapidly, and LPL activity decreased. On re-feeding and after injection of insulin the expression of ANGPTL4 and GPIHBP1 decreased rapidly, and LPL activity increased. In ANGPTL4 ${ }^{-/-}$ mice adipose tissue LPL activity did not show these responses. In old, obese rats that showed signs of insulin resistance, the responses of ANGPTL4 and GPIHBP1 mRNA and of LPL activity were severely blunted (at 26 weeks of age) or almost abolished (at 52 weeks of age).

Conclusions: This study demonstrates directly that ANGPTL4 is necessary for rapid modulation of LPL activity in adipose tissue. ANGPTL4 message levels responded very rapidly to changes in the nutritional state. LPL activity always changed in the opposite direction. This did not happen in Angpt/4 $4^{-/-}$mice. GPIHBP1 message levels also changed rapidly and in the same direction as ANGPTL4, i.e. increased on fasting when LPL activity decreased. This was unexpected because GPIHBP1 is known to stabilize LPL. The plasticity of the LPL system is severely blunted or completely lost in insulin resistant rats.
\end{abstract}

Keywords: Gene expression, Insulin, Gene inactivation, Cycloheximide, Actinomycin D, Transcription, Translation, Posttranslational

\footnotetext{
* Correspondence: Thomas Olivecrona@medbio.umu.se

'Department of Medical Biosciences/Physiological Chemistry, Umeå University, Umeå SE-90187, Sweden

Full list of author information is available at the end of the article
} 


\section{Background}

Lipoprotein lipase (LPL) is produced by parenchymal cells in some tissues (e.g. adipocytes, myocytes), secreted, and transported to the luminal side of capillaries. Here the enzyme hydrolyzes triglycerides in chylomicrons and VLDL and thereby makes fatty acids available for tissue metabolism. LPL activity is rapidly modulated by the nutritional state and plays a major role in distribution of fatty acids between tissues $[1,2]$.

The rapid daily modulations of LPL activity are mainly post-transcriptional [1-3]. One mechanism involves changes in the proportion of active to inactive species of the enzyme without significant changes in total LPL protein [4]. Down-regulation of adipose tissue LPL activity upon fasting requires that a gene, other than the LPL gene, is switched on [5]. This implies a protein that can transform LPL from an active to an inactive form. The fasting-induced, PPAR-responsive angiopoietin-like protein-4 (ANGPTL4) has emerged as a strong candidate for the role of such an LPL-controlling protein in adipose tissue [6,7]. In vitro studies show that ANGPTL4 interacts with LPL and converts active LPL dimers to inactive monomers [8,9]. Inactivation of Angptl4 in mice is associated with low plasma triglycerides and high postheparin LPL activity [10]. A special case is that Angptl4 ${ }^{-/-}$ mice on a diet with high content of saturated fat develop severe abdominal inflammation due to excessive LPLmediated lipid uptake in mesenteric lymph nodes [11]. Similarly, a loss of function mutation in ANGPTL4 in humans is associated with low levels of plasma triglycerides [12]. Conversely, overexpression of Angptl4 in mice results in low LPL activity and high plasma triglycerides $[10,13,14]$. Taken together these data convincingly show that ANGPTL4 is involved in modulating the activity of LPL and thereby metabolism of plasma triglycerides. It should be noted however that ANGPTL4 also has effects on angiogenesis and several other processes, and that there are additional members in the ANGPTL protein family that have effects on plasma lipid metabolism [15] .

Another protein important for LPL action is the newly discovered glycosylphosphatidylinositol-anchored high density lipoprotein-binding protein 1, GPIHBP1 [16]. This protein, which is expressed only in endothelial cells, is crucial for transfer of LPL to the luminal side of the capillary endothelium [17]. Inactivation of the gene for GPIHBP1 in mice results in gross chylomicronemia. Genetic deficiency in humans produces a clinical phenotype similar to that in LPL deficiency. It is not known if GPIHBP1 has any direct role in the modulation of LPL action. Like Angptl4 [6] the Gpihbp1 is PPAR-responsive [18], suggesting that the two genes might be similarly regulated.

A third, newly discovered, protein involved with the lipase system is the lipase maturation factor (LMF1). This is an ER-based chaperone which appears to be necessary for maturation of LPL and the related hepatic lipase and endothelial lipase into their active forms $[19,20]$.

In this paper we have explored how this landscape of LPL controlling proteins behaves in rat adipose tissue under a number of conditions previously shown to be associated with rapid changes of LPL activity. Specifically we have studied (1) if ANGPTL4 is needed for the rapid modulation of LPL activity; (2) if the message levels show circadian oscillations, (3) at what rates the messages for the three LPL-controlling proteins and the proteins themselves are being turned over, (4) how the messages for the LPL controlling proteins change on changes in the nutritional state, known to cause large changes of adipose tissue LPL activity and (5) what happens to the expression of the three proteins when rats become insulin resistant.

\section{Results}

\section{Circadian rhythm}

The expressions in adipose tissue of many of the genes involved in energy metabolism undergo circadian changes [21]. We followed the changes with time of day of a number of parameters related to LPL activity (Figure 1). Rats eat mainly during the dark period $(18: 00 \mathrm{~h}-6: 00 \mathrm{~h})$. Mean food consumption was $0.88 \pm 0.10 \%$ of body weight per hour during the night (Figure 1A). During the first hours of the light period $(6: 00 h-9: 00 h)$ the rats ate $0.04 \pm 0.01 \%$ of body weight per hour. This is less than $5 \%$ of what they ate per hour during the night. From 9:00 $\mathrm{h}-15: 00 \mathrm{~h}$ food consumption per hour was about one quarter of that during the dark period. During the last hours of the light period, 15:00 $\mathrm{h}-18: 00 \mathrm{~h}$, food consumption increased to about half of that during the dark period.

The changes in plasma glucose and non-esterified fatty acids (NEFA) over the day were moderate (Figure 1B). Adipose tissue LPL mRNA (Figure 1C) showed its highest value at 22:00 $\mathrm{h}$. This was 2.8 fold higher than the lowest value (at 10:00 $\mathrm{h}, \mathrm{p}=0.028$ ). Changes in GPIHBP1 mRNA (Figure $1 \mathrm{C}$ ) were modest and the tendency was opposite to that for LPL mRNA, with higher values during the light than during the dark period. The increase in ANGPTL4 mRNA during the light period was more pronounced compared to GPIHBP1, but the levels were down again by $18.00 \mathrm{~h}$. LPL activity (Figure 1D) in adipose tissue showed its highest value at 2:00 $\mathrm{h}$ and its lowest value at 10:00 h $(\mathrm{p}<0.01)$. The difference was about two-fold. LPL mass (Figure 1D) followed a similar pattern, and the ratio between LPL activity and mass (specific activity) did not change significantly.

\section{Response of the proteins studied and of LPL activity when mRNA or protein synthesis was blocked}

To directly study the turnover of the proteins involved, cycloheximide was injected in rats to block synthesis of 


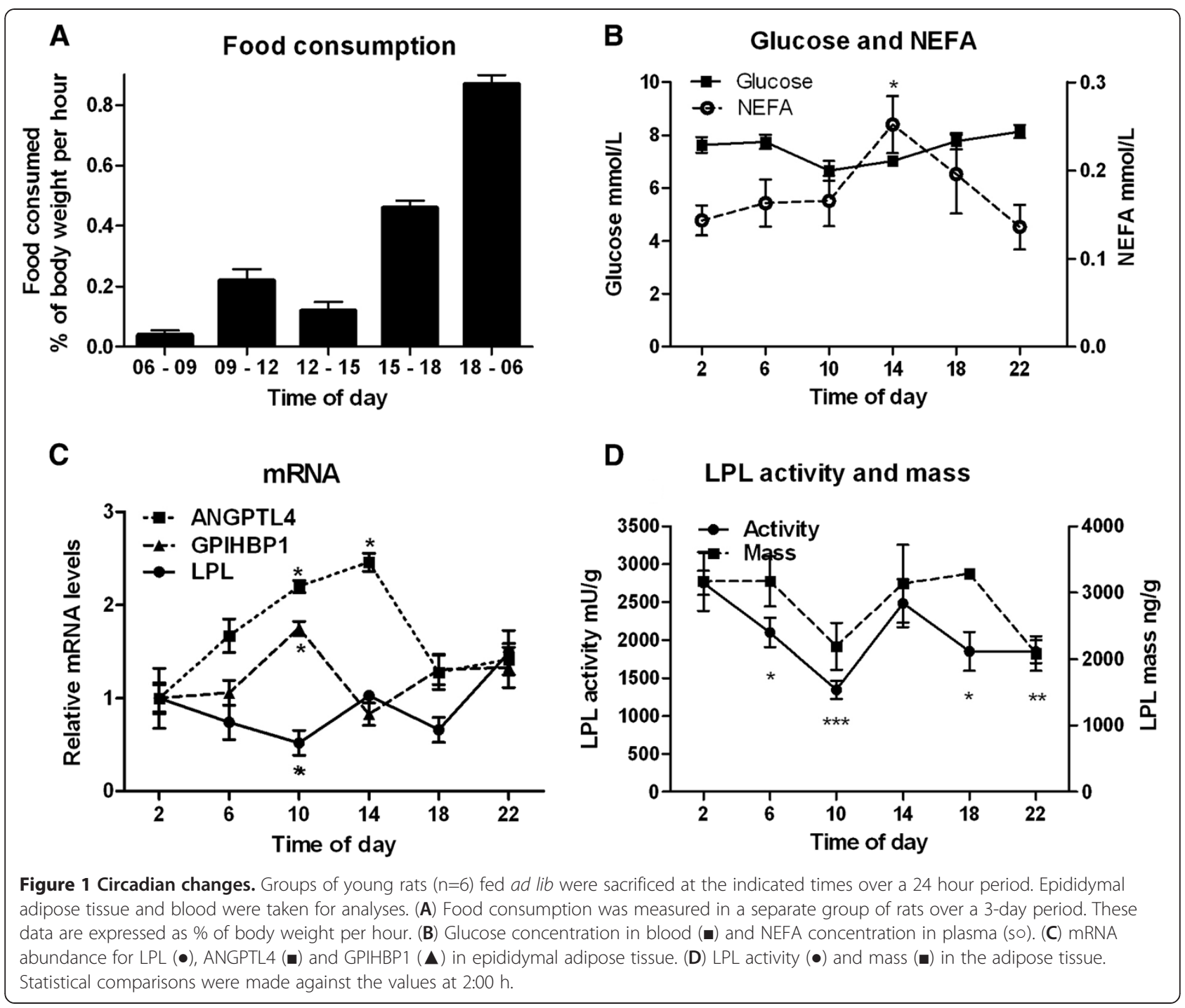

new proteins (Figure 2). LPL activity decreased by $60 \%$ in 3 hours (Figure 2A). LPL mass, measured by ELISA (Figure 2A), and estimated from Western blots (Figure 2D), decreased at a similar rate as the activity. These data are in line with earlier observations that the LPL protein turns over rapidly [22,23]. In contrast, ANGPTL4 protein showed bands of similar intensity on western blots throughout the four hours studied (Figure 2E and F). The pattern was the same when antibodies to the Cterminal (Figure 2E) or N-terminal domain (Figure 2F) of ANGPTL4 were used. Almost all of the protein was full length (here $68 \mathrm{kDa}$ compared to MW standards). With antibodies to the C-terminal domain small amounts of a $45 \mathrm{kDa}$ fragment was seen (Figure 2E), probably representing the fibrinogen-like domain of ANGPTL4. These data show that the ANGPTL4 protein turns over relatively slowly, much slower than the LPL protein. The turnover of the GPIHBP1 and LMF1 proteins could not be studied since suitable antibodies were not available.
To directly study the turnover of the corresponding messages, the transcription blocker actinomycin D (ActD) was injected (Figure 2). Fasted rats were used since the level of ANGPTL4 and GPIHBP1 messages in adipose tissue are several-fold higher in the fasted than in the fed state $[6,18]$. In concert with earlier studies [5], LPL activity in adipose tissue rose from $340 \pm 43$ to $1225 \pm 112 \mathrm{mU} / \mathrm{g}$ in six hours after ActD (Figure 2B). The value for LPL mRNA decreased by $8 \%$ by $4 \mathrm{~h}$ and by $33 \%$ by $6 \mathrm{~h}$ (Figure 2C), but these changes did not reach statistical significance. LPL mass as measured by the ELISA increased by $40 \%(\mathrm{p}<0.05)$ in $6 \mathrm{~h}$. Consistent with these data, Western blots showed that the level of LPL protein was essentially stable over the six h studied (Figure 2G). These data confirm that the LPL transcript is relatively stable.

While LPL activity went up, mRNA levels for ANGPTL4, GPIHBP1 and LMF1 were reduced by $93 \%, 75 \%$ and $29 \%$ by six hours after ActD (Figure 2C). These results show that the ANGPTL4 and GPIHBP1 transcripts are turned 


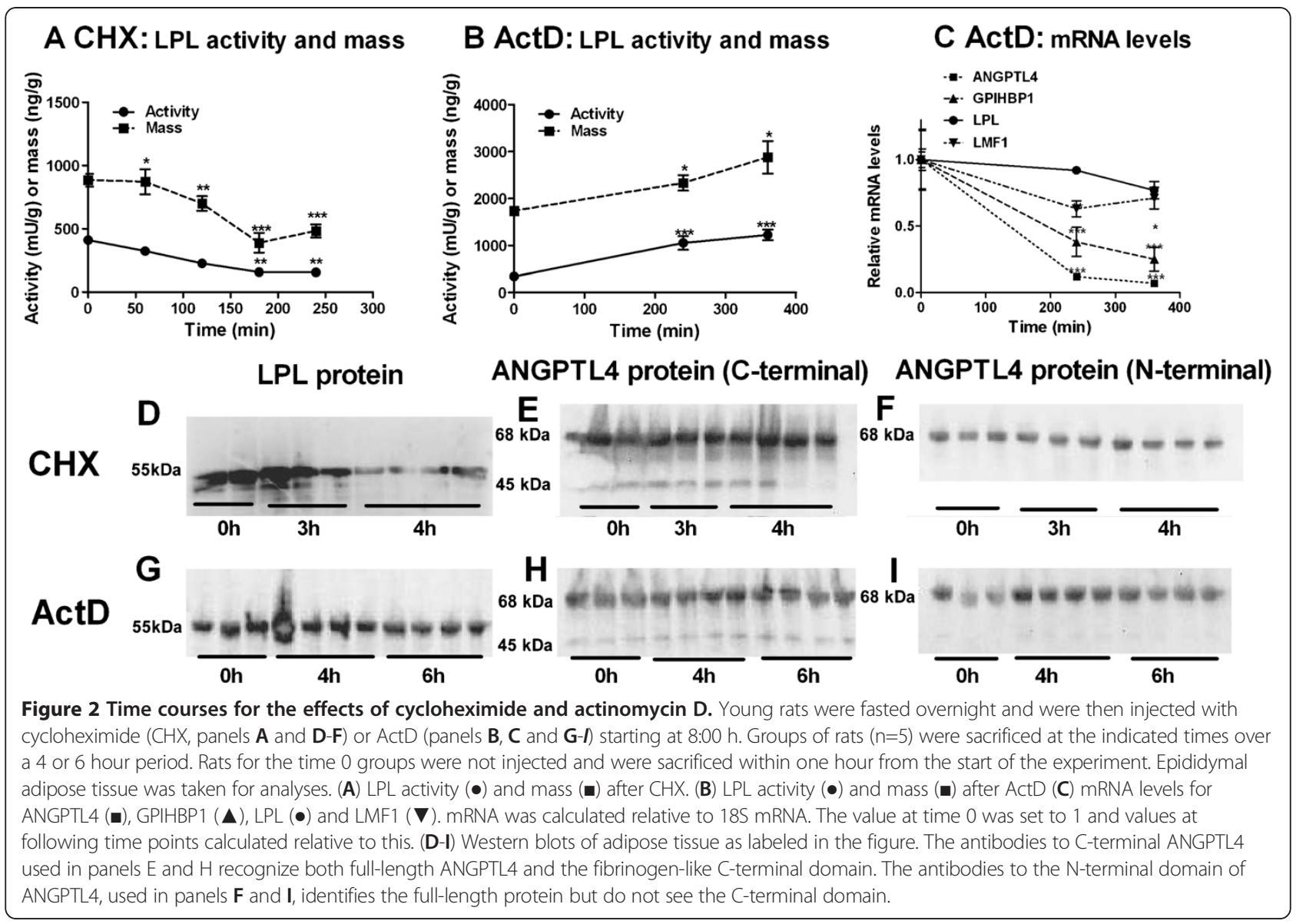

over rapidly. On Western blots, the ANGPTL4 protein showed bands of similar intensity throughout the six hours (Figure $2 \mathrm{H}$ and I). This pattern was the same when antibodies to the $\mathrm{C}$-terminal or $\mathrm{N}$-terminal domain were used. Almost all of the protein was full length but traces of a $45 \mathrm{kDa}$ fragment were seen with the antibody specific for the C-terminal domain of ANGPTL4. These data again show that the ANGPTL4 protein turns over relatively slowly.

\section{Early response to food withdrawal}

To study the early events in adaptation of the LPL system in adipose tissue to fasting, food was withdrawn from rats in the morning. At this time the animals ate rather little (Figure 1A). Their stomachs were about half full and emptied almost completely within two hours after food was removed. Insulin (Figure 3A) and glucose (Figure 3B) decreased whereas NEFA increased (Figure 3B). Triglycerides decreased, presumably because the inflow of chylomicrons from the intestine faded (data not shown). LPL mRNA in adipose tissue did not change significantly, in accordance with earlier observations [24] (data not shown). The level of mRNA for LMF1 also did not change significantly (data not shown).
In contrast, the levels of ANGPTL4 mRNA and GPIHBP1 mRNA increased markedly (about 6-fold and 2-fold, respectively) in adipose tissue over the six hours studied (Figure 3C). LPL activity in adipose tissue had decreased by $40 \%$ at four hours and by $53 \%$ at six hours (Figure 3D). In contrast there was no significant change of LPL mass (Figure 3D). All of these responses to food withdrawal were similar in a parallel experiment on female rats, but data are shown only for males. These data indicate that short term fasting is associated with reciprocal changes in adipose ANGPTL4 mRNA and LPL activity.

\section{Relation to changes in expression of other genes}

To get a perspective on the rapid and large response of Angptl4 transcript on fasting [8] we carried out an array analysis of the changes of RNA abundances in adipose tissue under the conditions used for our experiments. For this, food was removed from one group of rats in the early morning. Seven h later the rats were sacrificed, epididymal adipose tissue was cut out, RNA prepared and analyzed on Illumina arrays. $\mathrm{N}=6$ for both the fasted and the ad lib group. After filtering the data for $\mathrm{P}$ $<0.01$ and signal intensity $>50$, there remained 22 


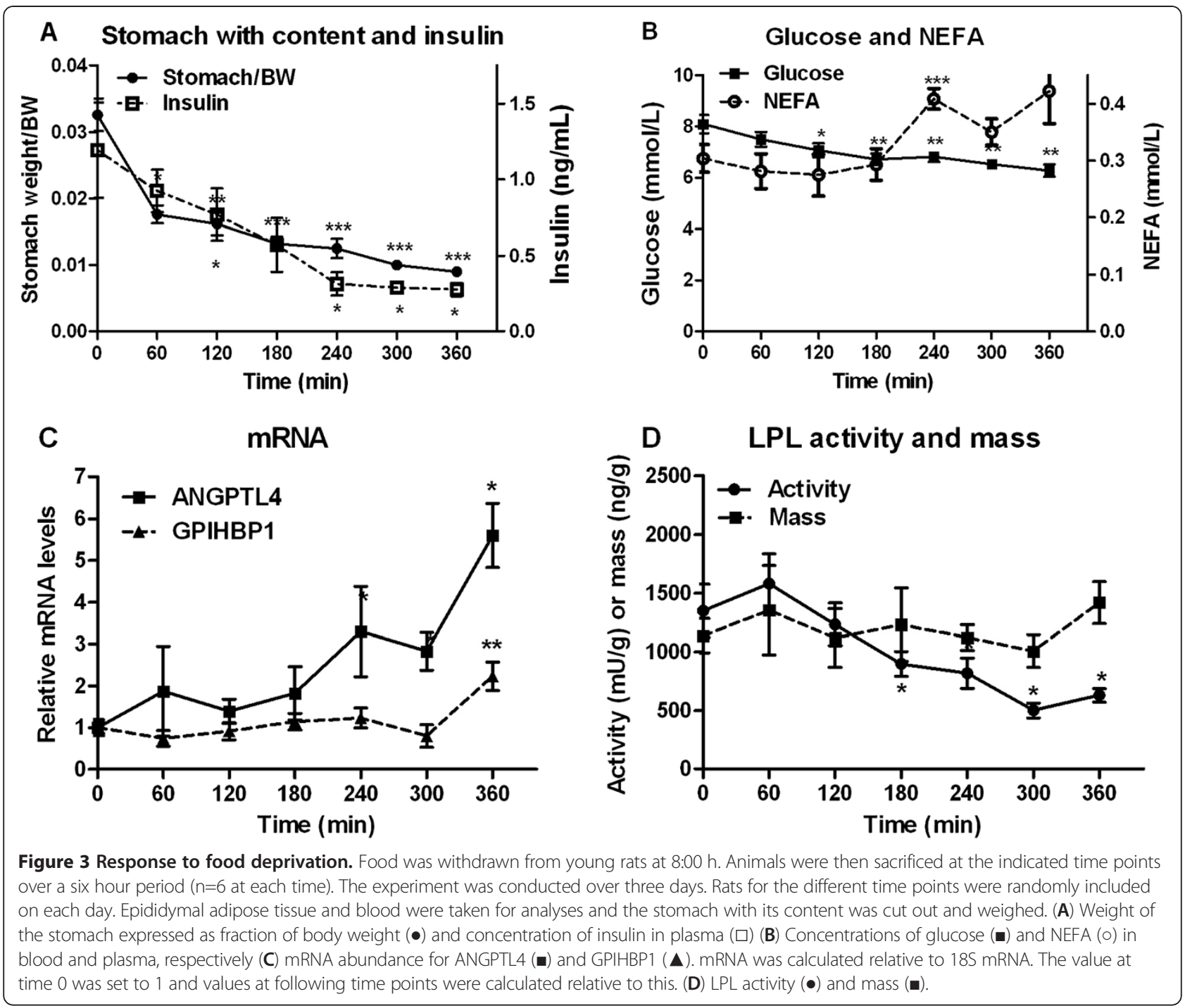

transcripts that had increased, and 21 that had decreased by a factor of 2.0 or more.

Sorting by foldchange+, Angptl4 came out as number four from the top (foldchange 3.37, $\mathrm{p}<\mathrm{E}$ " $10^{-17}$ ), preceded only by $P d k 4$, pyruvate dehydrogenase kinase 4 , a key regulator of glycolysis/glyceroneogenesis, Gpr109a, the ketone body/niacin receptor, a key regulator of lipolysis, and RGD1565690_predicted, a gene of unknown function (Table 1). In concert with the results of the experiment in Figure 3 and earlier observations [24], the expression of LPL did not change significantly (foldchange 1.02). Neither Gpihbp1 or LmfF1 was represented on this chip.

\section{Responses to re-feeding}

To study a situation when adipose tissue LPL activity increases rapidly we turned to re-feeding as a physiological model that we had used before [8]. For this, rats were fasted overnight and food was given back in the
Table 1 The eight genes that increased their expression in adipose tissue the most when food was removed

\begin{tabular}{lll}
\hline Symbol & Foldchange + & DiffScore \\
\hline Pdk4 & 4.97 & 70.6 \\
\hline Gpr109a & 3.86 & 54.8 \\
\hline RGD1565690_predicted & 3.83 & 55.7 \\
\hline Angpt14 & 3.58 & 330.8 \\
\hline Per1 & 3.25 & 39.4 \\
\hline Pfkfb3 & 3.15 & 12.7 \\
\hline Pck1 & 2.91 & 40.9 \\
\hline Net1 & 2.82 & 56.3 \\
\hline Lpl & 1.02 & 0.00004
\end{tabular}

Food was removed from one group of rats in the early morning. Seven $\mathrm{h}$ later the rats were sacrificed, epididymal adipose tissue was cut out, RNA prepared and analyzed on Illumina arrays. $\mathrm{N}=6$ for both the fasted and the ad lib group. Full data are deposited at NCBI GEO, accession no GSE 41800. 
morning. The animals started to eat within 5 to $10 \mathrm{~min}$. By one hour their stomachs contained $2.0 \pm 0.03 \mathrm{~g} / 100 \mathrm{~g}$ body weight (Figure 4A), similar to what was found in the stomach of regularly fed rats (Figure 3A). Insulin (Figure 4A) followed a time course similar to that for weight of stomach contents. Glucose increased (Figure 4B), and NEFA decreased (Figure 4B). ANGPTL4 and GPIHBP1 mRNA levels decreased rapidly and after two hours were only 35 and $21 \%$ of the initial levels, respectively (Figure 4C). LPL activity and mass increased (Figure 4D). Thus, similar to fasting, fasting-refeeding is associated with reciprocal changes in adipose ANGPTL4 and GPIHBP1 mRNA on the one hand, and LPL activity on the other hand.

Response of the LPL system to fasting and re-feeding in Angptl4 ${ }^{-/-}$mice

To directly investigate the role of ANGPTL4 in the rapid modulation of LPL activity we turned to studies in mice in which Angptl4 had been inactivated [10]. Groups of mice $(\mathrm{n}=6)$ were fed ad lib, fasted over night, or fasted over night and then re-fed in the morning for $3 \mathrm{~h}$. Plasma lipid levels were in accordance with previous results on Angptl4 ${ }^{-1-}$ mice [10]. Separation of lipoprotein classes by FPLC high-lighted that the fasted Angptl4 ${ }^{-/-}$mice had no TG in the VLDL fraction, while after re-feeding the levels of VLDL TG were similar in Angpt4 ${ }^{-/-}$compared to wildtype mice (Figure 5A). The peak of HDL cholesterol was slightly higher in Angptl4 ${ }^{-1-}$ and was shifted towards larger particles in all three groups of mice compared to wild-type (Figure 5A). The increase in NEFA on fasting was blunted in the Angptl4 ${ }^{-/-}$mice (Figure 5B). This is in accordance with a role of ANGPTL4 for intracellular lipolysis [25].

In the wild-type animals, fasting caused a decrease of adipose tissue LPL activity, as expected (Figure 6A). In contrast, fasting caused an increase of adipose tissue LPL activity in the Angptl4 ${ }^{-/-}$mice compared to fed or

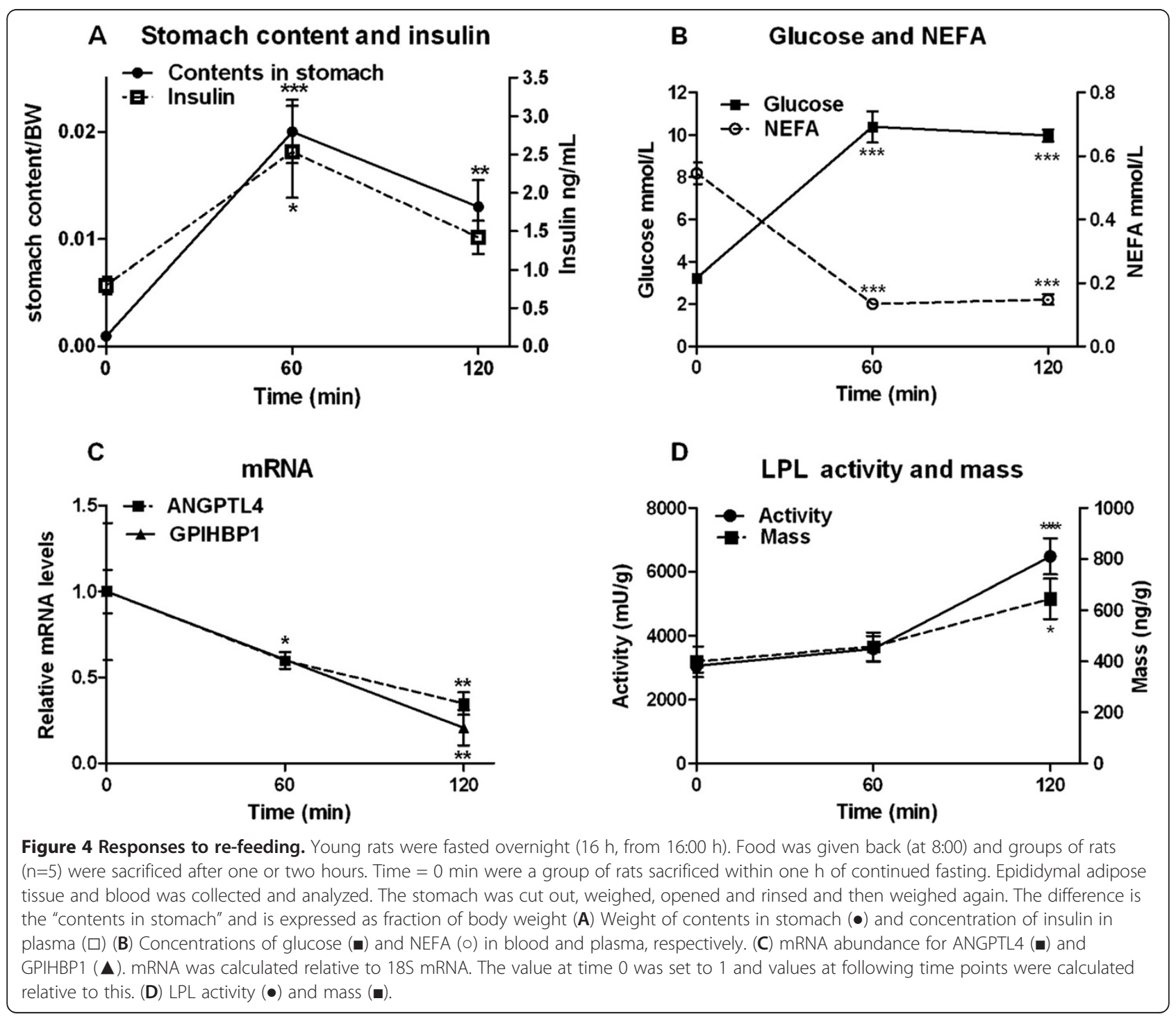



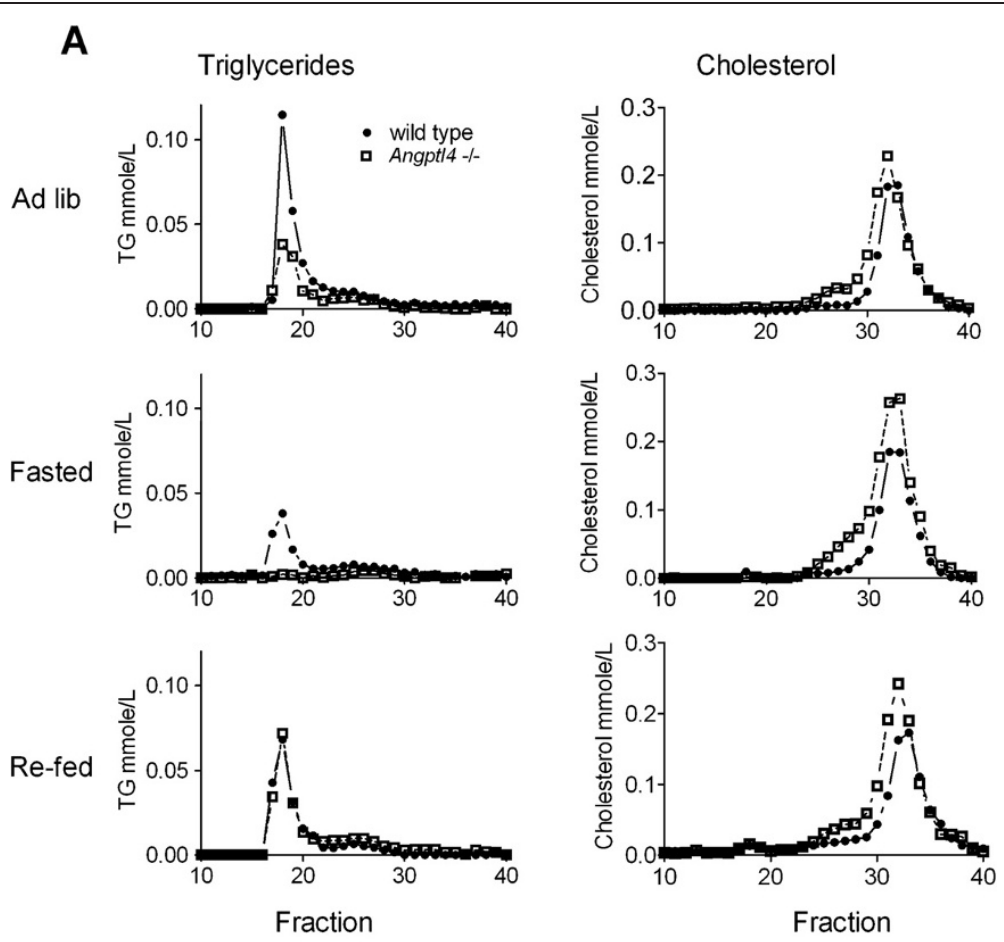

B

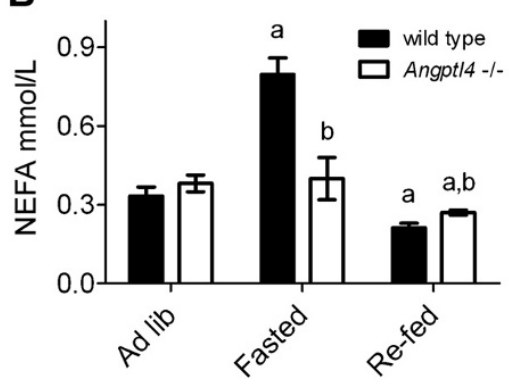

Figure 5 Plasma lipids in Angptl ${ }^{-/-}$mice. Wild-type and Angpt/ ${ }^{-/-}$mice were fasted overnight or fed ad lib. Food was given back to groups of fasted mice at 6:00 h (re-fed), while others continued fasting or eating ( $\mathrm{n}=6$ per group). All animals were sacrificed between 9:00 $\mathrm{h}-10: 00 \mathrm{~h}$. (A) FPLC analyses of pooled plasma samples representing the 6 different groups. (B) Fatty acids (NEFA) in individual plasma samples. Statistically significant $(p<0.05)$ differences are indicated by: a when comparing fasted or re-fed animals to ad lib for the same genotype $b$ when comparing the two genotypes for the same nutritional state.

re-fed Angptl4 ${ }^{-/-}$animals. LPL activity was significantly higher in all three nutritional states in Angptl4 ${ }^{-1-}$ compared to wild-type animals, indicating that ANGPTL4 represses LPL activity to some extent also in fed animals. ANGPTL4 mRNA was about two-fold increased in fasted compared to ad lib fed wild-type mice, while, as expected, there was no detectable ANGPTL4 mRNA in the Angptl4 ${ }^{-/-}$mice (Figure 6C). GPIHBP1 mRNA was also increased about two-fold in fasted wild-type mice compared to the fed groups. Interestingly, this difference was not seen in the Angptl4 ${ }^{-1-}$ mice (Figure 6D). LPL mRNA was not significantly changed in wild-type mice, but was decreased in the fasted Angptl4 ${ }^{-/-}$mice compared to the fed groups (Figure 6B). Taken together these data demonstrate that the reduction in adipose
LPL activity upon fasting is dependent on increased expression of ANGPTL4.

\section{Response to insulin}

To study direct effects of insulin on the LPL system, fasted rats were given an intraperitoneal injection of insulin, $1 \mathrm{U} / \mathrm{kg}$ body weight, which is in the range used for insulin tolerance tests in rodents [26]. The injection resulted in levels of insulin in blood that were about five times higher than the mean level in controls at $60 \mathrm{~min}$. Glucose and NEFA both decreased (data not shown). Already one hour after the injection, adipose tissue LPL activity had almost doubled (Figure 7). LPL mass did not change significantly (data not shown). ANGPTL4 and GPIHBP1 mRNA both decreased (Figure 7). One hour 


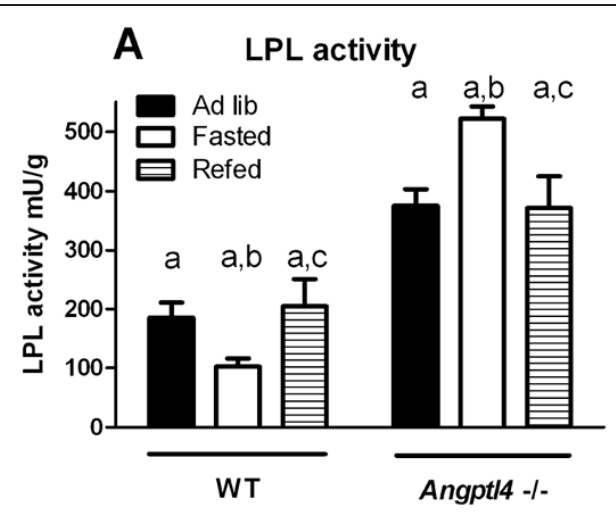

\section{B LPL mRNA}

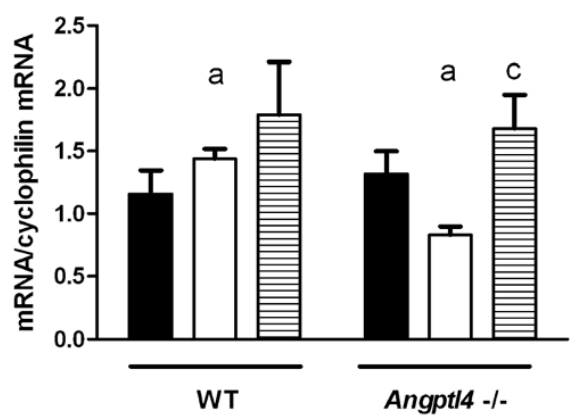

C ANGPTL4 mRNA

D GPIHBP1 mRNA
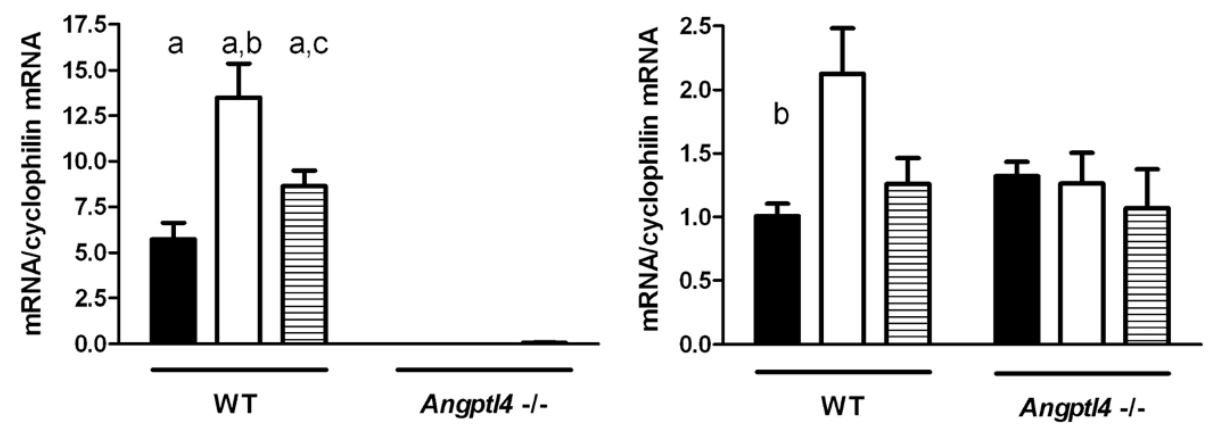

Figure 6 Response of the LPL system to fasting and re-feeding in Angptl4 ${ }^{-/-}$mice. Epididymal adipose tissue from the same mice as described in Figure 5 was cut out and analyzed for LPL activity and mRNA abundance for LPL, ANGPTL4, and GPIHBP1. The levels of mRNA were

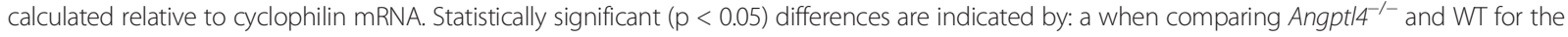
same nutritional state $\mathrm{b}$ when comparing fasted and ad lib for the same genotype $\mathrm{c}$ when comparing refed and ad lib for the same genotype.

after injection of insulin the levels were $33 \%$ and $50 \%$ of the initial levels, respectively.

\section{Changes with age and/or weight of the rats}

Previous studies have shown that the response of adipose tissue LPL activity to feeding/fasting is blunted in old, obese rats [5,27]. To probe this we studied rats at three different ages, 5 weeks old, lean, body weight $199 \pm 20$ g; 25 weeks old, moderately obese, body weight $695 \pm 66$ g; and 52 weeks old, grossly obese, body weight $1006 \pm 82 \mathrm{~g}$. One set of rats from each age group was fasted overnight and compared to $a d$ lib fed controls.

In the fasted state, the young lean rats had low blood glucose, about $3.3 \mathrm{mmol} / \mathrm{L}$. The intermediate and old rats had much higher blood glucose, about $6.0 \mathrm{mmol} / \mathrm{L}$ (Figure 8A). In the fed state the three groups had similar blood glucose levels, around $8 \mathrm{mmol} / \mathrm{L}$. The fed/fasted ratio for glucose was around 2.3 in the young, lean rats, but only 1.3 and 1.2 in the old and intermediate groups, respectively. NEFA levels were similar in all three groups in the fed state (Figure 8B). On fasting, the level increased almost three-fold in the young rats, but did not change significantly in the intermediate or old rats.
Plasma insulin levels (Figure 8C) showed large differences between the groups. The fasting level was below $0.6 \mathrm{ng} / \mathrm{ml}$ in the young rats, four times higher in the intermediate group and 12 times higher in the oldest group. The fed/fasted ratio was about 5 in the young lean rats, but only 1.35 in the intermediate group. In the old group insulin levels in plasma did not differ between fed or fasted animals.

In accordance with the observations for food withdrawal (Figure 3) and re-feeding (Figure 4), ANGPTL4 and GPIHBP1 mRNA levels were much higher in the fasted than in the fed state in the young rats (Figure 8D and E). In contrast there were no statistically significant changes with nutritional state in the older rats.

Adipose tissue LPL activity, expressed per gram wet tissue weight, was high in the young rats, about $1600 \mathrm{mU} / \mathrm{g}$. In the intermediate and old rats the activity was less than one-third (Figure 8F). These rats had much larger fat pads than the young lean ones so that the total LPL activity per pad was actually larger in the older groups (2.1-fold and 3.6-fold for the intermediate and old rats, respectively), compared to the young rats. Remarkably, the response to nutritional state was more 


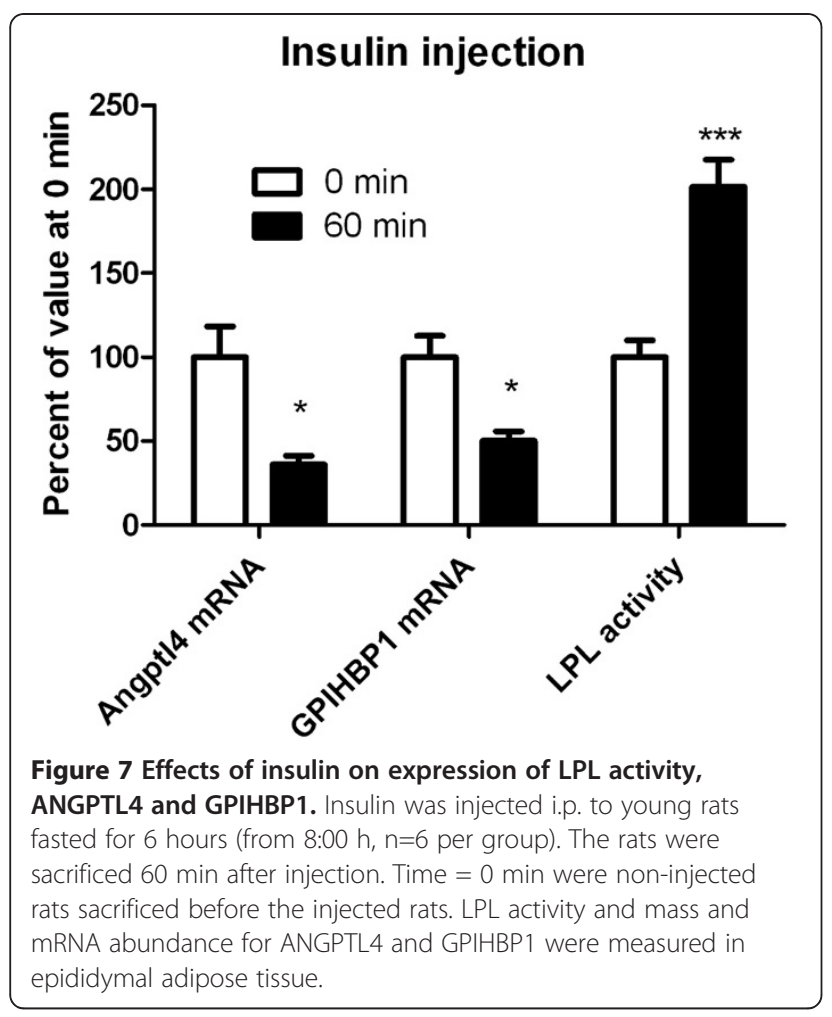

pronounced in the young rats with a fed/fasted ratio more than twice as high as that in the two older groups (Figure 8F).

\section{Discussion}

The present study reinforces previous observations that rapid modulation of LPL activity (in rodent adipose tissue) is not exerted at the level of LPL gene expression $[1,24,27,28]$. LPL mRNA levels remained essentially stable under the conditions we tested. Likewise, the mRNA for LMF1, an ER protein needed for proper maturation of LPL into its active form [19,20], did not change significantly, in accordance with an earlier study in Zucker diabetic rats [29]. In contrast, the mRNAs for ANGPTL4 and GPIHBP1, changed much more rapidly than most mRNAs in mammalian cells [30]. These two proteins interact with LPL and we will designate them collectively as 'LPL controlling proteins'. There may well be more, yet undiscovered, proteins that participate in the LPL system. A major mechanism for the modulation of adipose LPL activity is conversion of catalytically active LPL dimers into inactive monomers $[4,8]$. This process is virtually irreversible $[31,32]$. The LPL protein, active or inactive, turns over with a half-life of less than two hours $[22,23]$ which is much more rapid than the

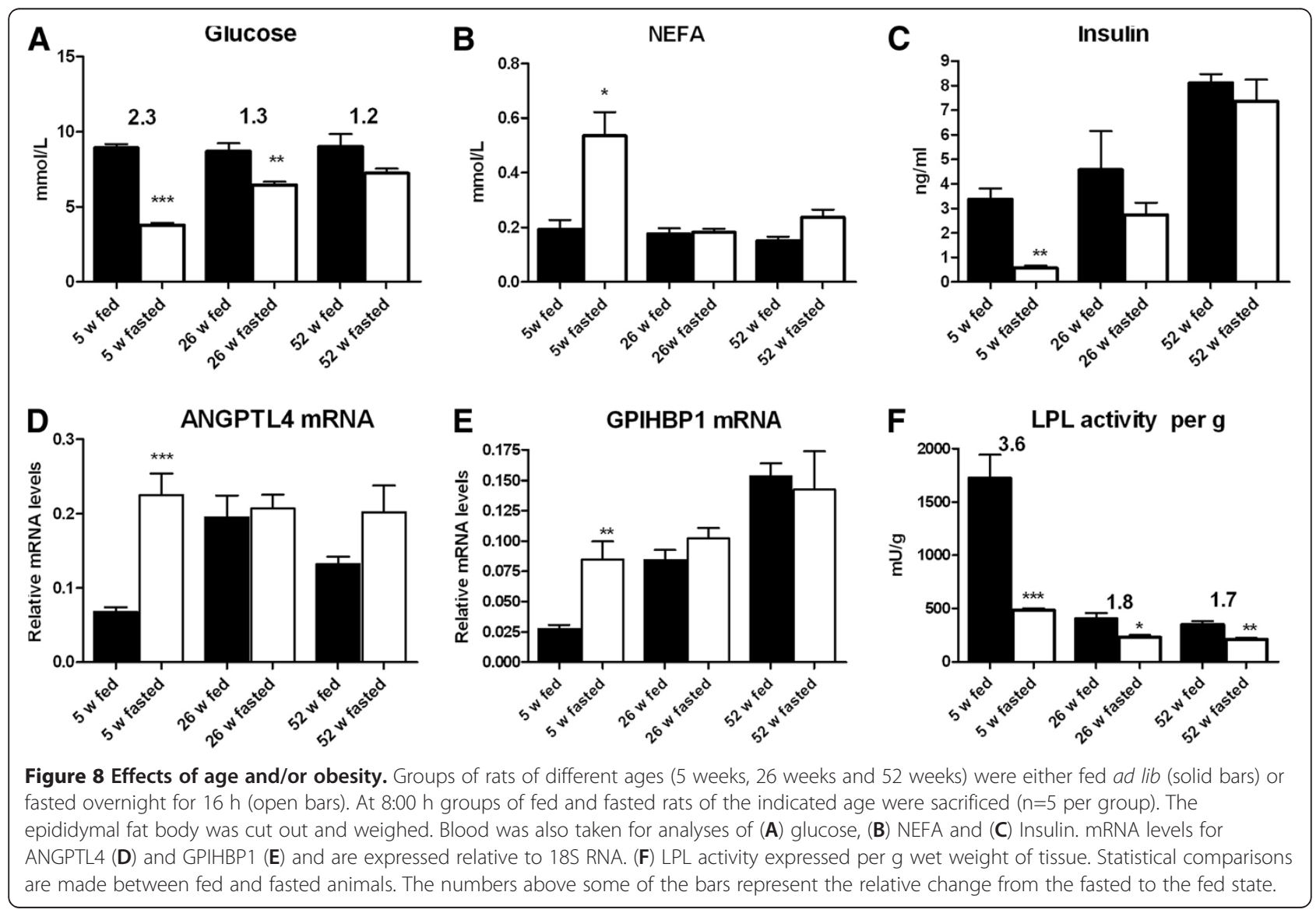


turnover of most proteins in mammalian cells [30]. Hence, the overall design of the LPL system appears to be relatively constant production and secretion of shortlived enzyme molecules that either retain or loose their catalytic activity in response to a number of controlling proteins. This design may have evolved to meet the need to modulate the activity of secreted/extracellular LPL molecules.

The expression of many genes involved in energy metabolism undergo profound circadian oscillations in the adipose tissue presumably to adapt the animal to predictable changes in the environment [21], LPL mRNA, mass and activity all shoved higher values in the middle of the dark period. For LPL activity the amplitude was about two-fold, in accordance with previous studies [24,33-37]. ANGPTL4 and GPIHBP1 mRNA showed modest changes opposite in direction to that for LPL. Hence, it appears that the LPL system displays a moderate circadian oscillation in phase with the eating behavior, but can respond rapidly and profoundly whenever food becomes scarce. Of note, the circadian oscillations of adipose tissue LPL are more pronounced in mice, with a more than three-fold higher activity in the middle of the dark period compared to the middle of the light period [38]. A significant circadian variation has also been reported for post-heparin LPL activity in humans [39].

A possible confounding factor for studies of how LPL activity is modulated in adipose tissue is changes in the rate at which proteins are being synthesized in the adipocytes [1]. Parkin et al. found that insulin more than doubled the rate of incorporation of amino acids into proteins in rat fat pads and caused a corresponding increase in LPL activity [40]. Other groups have reported similar observations [1,2]. Kern and his associates have described a more specific mechanism that affects LPL synthesis whereby stimulation of the protein kinase A system leads to formation of a protein complex that binds to the 3'UTR of LPL mRNA and blocks its translation [28]. It seems likely that part of the early responses of LPL activity in our studies, e.g. after injection of a large dose of insulin, reflect decreased/increased rates of LPL translation. This can not, however, fully explain the changes seen. For instance, during food deprivation (Figure 3) LPL activity decreased by more than $50 \%$, while there was no significant change in LPL mass.

The experiment on Angptl4 ${ }^{-/-}$mice clearly demonstrated the important role of ANGPTL4 for suppression of adipose tissue LPL activity in the fasted state. Even though LPL mRNA levels were significantly reduced in adipose tissue of the Angptl4 ${ }^{-/-}$mice, compared to all other groups of mice, LPL activity was the highest in adipose tissue of fasted Angptl4 ${ }^{-1-}$ mice. Also in the ad $l i b$ fed and the re-fed states, adipose tissue LPL activity was significantly higher in Angptl4 ${ }^{-/-}$mice than in wild- type mice, indicating that some LPL is depressed by ANGPTL4 even under conditions when LPL activity is at demand. These data are compatible with those of Köster et al. [10], demonstrating 2-3 fold higher LPL activity in post-heparin plasma in Angptl4 $^{-/-}$mice compared to wild-type mice in both fed and fasted animals. Similarly, blocking transcription by ActD led to a decrease in ANGPTL4 mRNA levels in adipose tissue and to a 3-fold increase in LPL activity in fasted rats [8], and to a 3-fold increase in post-heparin plasma LPL activity in ad lib fed rats [41]. In fed animals, most of the LPL activity in post-heparin plasma originates from adipose tissue, while in fasted animals the dominating source is presumably skeletal muscle and heart $[38,42]$. Taken together the data demonstrate that ANGPTL4 is an important modulator of LPL activity in both fasted and fed animals.

The present data show that ANGPTL4 mRNA turns over rapidly in adipose tissue, in concert with an earlier study [8]. When transcription was blocked by injection of ActD, the mRNA decreased more than $90 \%$ in 4 hours. The mRNA level responded rapidly to the perturbations of the nutritional state that we used. It increased more than $200 \%$ from 3 to 6 hours after food deprivation. It decreased by about $50 \%$ in one hour after injection of insulin and by about $65 \%$ within two hours after refeeding of rats that had fasted overnight. In all of these situations, the expression of Angptl4 changed as expected for a gene that negatively controls LPL activity. Whenever the expression of Angptl4 increased, LPL activity decreased and conversely when the expression of Angptl4 decreased, LPL activity increased. The time courses for the changes were compatible with a major role for ANGPTL4 in modulation of LPL activity, if one takes into account that the general rate of protein synthesis, and hence LPL synthesis, probably changed (see above). In contrast to the rapid changes of ANGPTL4 message levels, the ANGPTL4 protein remained essentially unchanged over several hours, as evaluated by Western blots. This was true whether we used antibodies to the $\mathrm{N}$-terminal or $\mathrm{C}$-terminal domains, and was true both in experiments where syntheses of new protein was blocked by cycloheximide and in experiments where message levels changed several-fold in response to a transcription block or in response to food withdrawal, re-feeding or insulin injection. This suggests compartmentalization, such that only newly synthesized ANGPTL4 protein can inactivate LPL. Within cells the ANGPTL4 protein exists as monomers but they form oligomers when they reach the cell surface [43]. It is only after oligomerization that the ANGPTL4 protein can interact with and inactivate LPL $[12,43]$. Hence, it is possible that LPL and ANGPTL4 monomers do not interact when they travel through the secretory pathway, 
but there is a critical event when the proteins emerge at the cell surface that triggers oligomerization of ANGPTL4 and thereby inactivation of LPL. LMF1 may have a role here [20]. Once LPL transfers to the endothelial cells the enzyme may be rescued by interaction with heparan sulfate proteoglycans [44] and/or GPIHBP1 [45].

The message for GPIHBP1 also turned over rapidly. When transcription was blocked by ActD the message decreased by more than $60 \%$ within 4 hours. It increased 4-fold from 3 to 6 hours after food deprivation. It decreased by about $50 \%$ in one hour after injection of insulin and by about $80 \%$ within 2 hours after re-feeding of overnight fasted rats. This is in accordance with the studies of Davis et al. who found that GPIHBP1 message in adipose tissue is higher in $16 \mathrm{~h}$ fasted than in fed rats [18]. Comparing the amplitudes of the changes, Gpihbp1 was at least as responsive as Angptl4. This is impressive considering that array analysis showed that Angptl4 was one of the genes whose expression had increased most seven hours after food withdrawal (Table 1). The changes of GPIHBP1 mRNA were in the same direction as the changes of ANGPTL4 mRNA in all the situations that we studied. This is surprising. According to present hypotheses ANGPTL4 protein suppresses LPL activity. GPIHBP1 on the other hand stabilizes the enzyme and promotes its delivery to the site of action at the vascular endothelium [45]. One should note that the changes presumably take place in different cells in the tissue. Gpihbp1 is expressed in endothelial cells [16] whereas Angptl4 is presumably expressed mainly in adipocytes. It is possible that GPIHBP1 not only delivers LPL to the luminal side of the endothelium, but that under certain circumstances, like during fasting, GPIHBP1 may predominantly transport LPL in the opposite direction leading to LPL-inactivation and or degradation within the tissue [46].

Rapid, tissue-specific modulation of LPL activity is important for whole body energy homeostasis by directing lipid uptake to the appropriate tissues and limiting the need for re-transport [1,2]. Earlier studies have shown that the response of adipose tissue LPL activity to feeding-fasting becomes blunted as rats grow older and become obese $[5,24]$. The present study confirms these observations and links them to the development of insulin resistance. In young, lean rats (5 weeks old) adipose tissue LPL activity decreased by a factor of $3.6-3.9$ on fasting overnight. In older, obese rats the response was less than half, 1.7 - 1.9-fold. The older rats appeared to be insulin-resistant. Fasting blood glucose and insulin was elevated compared to the young rats and the difference fed versus fasted was less for all parameters studied. It is of interest to note that these rats were not manipulated in any way but housed by normal routines and fed chow ad lib [47]. The responses of the LPL controlling genes, Angptl4 and Gpihbp1 were blunted. The large change in GPIHBP1 mRNA (about 3-fold) seen when young rats were fasted was completely abolished in the older rats. For ANGPTL4 mRNA some response remained but it was much less than in the young rats. It is of interest to note that the values seen in either the fed or fasted state in the older rats were similar to those seen in fasted young rats. Hence, it appears that it was the ability to down-regulate the expression in the fed state that caused the loss of metabolic plasticity. In line with this it was recently shown that mRNA of Angptl4 is upregulated in diabetic mice [48] whereas insulin inhibited Angptl4 mRNA expression in 3 T3-L1 adipocytes [49]. Moreover, FFA, which are increased in the insulin-resistant state, were shown to upregulate mRNA expression of Angptl4 in human adipocytes [50]. A study on groups of human subjects (young, lean compared to old, obese with or without diabetes type II) demonstrated a blunting of the response of Angptl4 to feeding/ fasting in both groups of elderly individuals compared to the young, while no effect was in this case seen on GPIHBP1 expression [42]. Bergö et al. found that blocking transcription by ActD (which relieves the suppression of LPL activity) increased adipose tissue LPL activity severalfold in fasted young rats, but had only a small effect in old, obese rats [5]. These data are compatible with the hypothesis that expressions of Angptl4 and/or Gpihbp1 are main determinants for LPL activity in adipose tissue of rats.

Modulation of LPL activity is important for partitioning of lipids between tissues in accordance with changes in the metabolic situation $[1,2]$. It is becoming evident that that modulation of LPL action occurs by interplay of several factors. The central player, the LPL enzyme, appears to be produced at a relatively constant rate. The activity and the distribution of the enzyme between the endothelial cell surface and other places in the tissue are determined by LMF1, ANGPTL14 and GPIHBP1 and perhaps other proteins in a context dependent manner. In addition LPL action is modulated by factors pertaining to the lipoprotein substrate [1]. Apolipoprotein CII is a necessary cofactor. Apolipoprotein CIII and other apolipoproteins can suppress lipase action. In this case the action of the enzyme is inhibited but not irreversibly lost.

\section{Conclusions}

The main conclusion from this study is that ANGPTL4 is necessary for the rapid modulation of LPL activity in adipose tissue. ANGPTL4 message levels responded very rapidly to changes in the nutritional state. LPL activity always changed in the opposite direction. This did not happen in Angptl4 ${ }^{-/-}$mice. GPIHBP1 message levels also changed rapidly and in the same direction as ANGPTL4, i.e. increased on fasting when LPL activity decreased. This was unexpected because GPIHBP1 is known to stabilize LPL. 
In old, obese rats that showed signs of insulin resistance, the responses of ANGPTL4 and GPIHBP1 mRNA and of LPL activity were severely blunted (at 26 weeks of age) or almost abolished (at 52 weeks of age). Hence, the plasticity of the LPL system is severely blunted or completely lost in insulin resistant rats.

\section{Methods}

\section{Animal procedures}

Inbred male Sprague-Dawley rats weighing 150-210 g were used, except in the exp on the effect of ageing/insulin resistance in Figure 8. The rats were housed with free access to a standard pellet diet and water in a 12 -h light cycle $(6: 00 \mathrm{~h}-18: 00 \mathrm{~h})$. Experiments were, unless otherwise stated, carried out with rats fed or fasted overnight (food removed at 16:00 h) or fasted for $6 \mathrm{~h}$ (food removed at 8:00 h). During fasting the rats were kept in cages with a perforated floor to prevent coprophagia. In experiments with re-feeding, rats were fasted overnight and then food was given back at 8:00 h. The experiment then continued for $2 \mathrm{~h}$. The rats were killed by decapitation. The fat depot studied was the epididymal. Tissues were collected into Eppendorf tubes and immediately frozen in liquid nitrogen. Blood samples to be analyzed for LPL activity and metabolites were collected in EDTA blood collection tubes (Sarstedt). Plasma was obtained by centrifugation of the blood at $4^{\circ} \mathrm{C}$ and the samples were then stored at $-70^{\circ} \mathrm{C}$. the bars represent the relative change from the fasted to the fed state

Male pure-bred WT and Angptl4-/- mice on a C57Bl/6 background between ages 4-6 months were used [10]. Fasted mice were fasted from 15:00 $\mathrm{h}$ and sacrificed the next day between 9:00 $\mathrm{h}$ and 10:00 $\mathrm{h}$. Refed mice were fasted from 15:00 $\mathrm{h}$, refed with chow the next day at 6:00 $\mathrm{h}$ and sacrificed between 9:00 $\mathrm{h}$ and 10:00 h. Mice were anaesthetized with a mixture of isoflurane (1.5\%), nitrous oxide (70\%) and oxygen (30\%). Blood was collected by orbital puncture into EDTA tubes. Mice were killed by cervical dislocation, after which tissues were excised and directly frozen in liquid nitrogen.

All animal procedures were approved by the local animal ethics committees in Umeå (rats) and Wageningen (mice), respectively.

In experiments on rats, insulin (Actrapid, Novo Nordisk $\mathrm{A} / \mathrm{S}$, Denmark) was injected intraperitoneally $(1 \mathrm{U} / \mathrm{kg} \mathrm{bw})$ to rats fasted for $6 \mathrm{~h}$. Controls were injected with saline only. Actinomycin D (Sigma Aldrich), dissolved in pure ethanol to a concentration of $2 \mathrm{mg} / \mathrm{ml}$, was injected intraperitoneally ( $2 \mathrm{mg} / \mathrm{kg} \mathrm{bw}$ ) to rats fasted for $6 \mathrm{~h}$. Controls were injected with ethanol. Cycloheximide (Sigma Aldrich), dissolved in saline to a concentration of $35 \mathrm{mg} /$ $\mathrm{ml}$, was injected intraperitoneally $(35 \mathrm{mg} / \mathrm{kg} \mathrm{bw})$ to rats fasted for $16 \mathrm{~h}$. Controls were injected with saline.

\section{LPL activity assay}

Frozen tissues were homogenized in 9 volumes of buffer at $\mathrm{pH} 8.2$ containing $0.025 \mathrm{M}$ ammonia, 1\% Triton X-100, $0.1 \%$ SDS and protease inhibitor cocktail tablets (Complete Mini, Roche Diagnosis, Germany) using a Polytron PT 3000 Homogenizer (Kinematica). The homogenates were centrifuged for $15 \mathrm{~min}$ at $10,000 \mathrm{rpm}, 4^{\circ} \mathrm{C}$. Aliquots of the supernatants were used for determination of LPL activity as previously described [5] using a phospholipidstabilized emulsion of soy bean triacylglycerols and ${ }^{3} \mathrm{H}$ oleic acid-labeled triolein with the same composition as Intralipid 10\% (Fresenius Kabi, Uppsala, Sweden). The incubation was at $25^{\circ} \mathrm{C}$ for 100 or $120 \mathrm{~min}$. One milliunit of enzyme activity corresponds to $1 \mathrm{nmol}$ of fatty acids released per min. Enzyme activity is expressed per g wet tissue weight. In the exp in Figure 8 LPL activity per whole epididymal fat pad was also calculated. All samples were assayed in triplicates.

\section{LPL mass determination}

Mass was measured by an Elisa method previously described [4,5]. Affinity purified immunoglobulins (IgY) from chicken, raised against bovine LPL were used for capture of the antigen during an overnight incubation. Bound LPL was detected with 5D2 monoclonal antibody raised against bovine LPL (a generous gift from Prof. J. Brunzell, University of Washington, Seattle WA), followed by detection with peroxidise-labelled anti-mouse IgG. LPL purified from bovine milk was used as standard.

\section{Quantitative RT-PCR analyses}

For determination of the levels of LPL, ANGPTL4, GPIHBP1 and LMF1 mRNA in rat tissues, total RNA was extracted from adipose tissues using TRIzol reagent (Life Technologies) and treated with DNA-free kit (Ambion). cDNA was prepared from $50 \mathrm{ng}$ total RNA using Moloney Murine Leukemia Virus Reverse Transcriptase, RNase $\mathrm{H}$ Minus (Fermentas) and $\operatorname{pd}(\mathrm{N})_{6}$ Random Hexamer (Fermentas) in total volume of $20 \mu \mathrm{l}$. The expression of the genes of interest were quantified by real time PCR using TaqMan Universal PCR Master Mix and the ABI Prism 7700 Sequence Detection System (Applied Biosystems, Foster City, CA) and normalized to endogenous control (18S rRNA). ANGPTL4, LPL, GPIHBP1 and LMF1 primers and probes were designed from the published sequences for rat ANGPTL14, LPL, GPIHBP1 and LMF-1 (corresponding GenBank accession numbers are: NM_199115, NM_000237, NM_001130547, and XM_340769. The sequences for primers and probes used were as follows:

\section{5'-Fam-CTTGGAGCCCATGCTGCTGGC-TAMRA (LPL probe)}




\section{5'-ACTGGTGGGACAGGATGTGG \\ (LPL forward primer) \\ 5'-CCGTTCTGCATACTCAAAGTTAGG \\ (LPL reverse primer) \\ 5'-Fam-TCCCCAAGGCGAGTTCTGGCTG- TAMRA \\ (ANGPTL4probe) \\ 5'-GACGCCTGAACGGCTCTGT \\ (ANGPTL4forward primer) \\ 5'-CCCCTGTGATGCTGTGCAT \\ (ANGPTL4reverse primer) \\ 5'-Fam-TGCCAGCACGAAATTCTCCCCG-TAMRA \\ (GPIHBP1 probe) \\ 5'-TCAAAGGCTCATTCTCATCTTGA \\ (GPIHBP1 forward primer) \\ 5'-ACACTCTTGGTTTCCTTCCAACA \\ (GPIHBP1 reverse primer) \\ 5'-Fam CGCTTTCATTTACTTTGTGGCCTTCTTGG- \\ TAMRA (LMF1 probe) \\ 5'-CAGCCTGGCTACACACGGGC \\ (LMF1 forward primer) \\ 5'-CAGCCAGTGCTGCCGTGGAA \\ (LMF1 reverse primer)}

Expression levels were normalized to 18S rRNA using the Eukaryotic18S rRNA Endogenous Control Reagent Set supplied from Applied Biosystems. All calculation was done in accordance with recommendation from Applied Biosystems (User Bulletin \#2).

For analyses of mRNAs for LPL, GPIHBP1 and ANGPTL4 in mouse adipose tissue, total RNA was isolated with TRIzol reagent (Invitrogen, Breda, The Netherlands) according to manufacturer's instructions. One $\mu \mathrm{g}$ of total RNA was reverse transcribed using iScript (Bio-Rad, Veenendaal, The Netherlands). cDNA was amplified on a Bio-Rad CFX384 Real Time System using Sensimix (Bioline, GC Biotech, Alphen aan de Rijn, The Netherlands). Cyclophilin was used as housekeeping gene. PCR primer sequences were taken from the PrimerBank and ordered from Eurogentec (Seraing, Belgium). Sequences of the primers used are available upon request.

\section{Gene expression array}

Food was removed from one group of rats $(n=6)$ at $1: 30 h$ while another group $(\mathrm{n}=6)$ remained fed $a d$ lib. The animals were killed starting from 8:15 h and epididymal adipose tissue was collected. Aliquots of total RNA were converted to biotinylated double-stranded cRNA using Illumina Totalprep RNA Amplification Kit according to manufacturer's instructions (Ambion, Austin, TX, USA). The labeled cRNA samples were hybridized to RatRef-12 Expression BeadChip (Illumina, San Diego, CA, USA), incubated with streptavidin-Cy3 and scanned on the Illumina Beadstation GX (Illumina, San Diego, CA, USA). To determine differentially expressed genes microarray data were analyzed using Illumina Beadstudio software (version 3.3). The data were normalized and significant differential expression was calculated using Beadstudio's cubic spline algorithm. False discovery rate was applied. The gene expression fold change for the fasted group was calculated as the average signal value relative to the average signal value for the ad lib fed group. Statistical significance cutoff was set to $\mathrm{P}<0.01$; minimum signal intensity was set at $50 \mathrm{~A}$. Full data are deposited at NCBI GEO, accession no GSE41800.

\section{Western analyses}

The same homogenates as prepared for assay of LPL activity and mass were used. Protein was determined by the BDH protein assay (Pierce) and $20 \mu \mathrm{g}$ of total protein was separated on 4-20\% Tris-glycine gradient gels (Lonza), and blotted onto PVDF membranes (Hybone-C, Amersham Biosciences). The membranes were blocked by ECL Advance blocking agent (GE Healthcare). For detection of LPL we used a rabbit polyclonal antibody from Santa Cruz Biotechnology at a dilution of 1:2000. For detection of ANGPTL4 we used a polyclonal goat antihuman antibody against the N-terminal domain $(\mathrm{N}-15$, Santa Cruz Biotechnology), a goat polyclonal anti-mouse against the C-terminal domain (L-17, Santa Cruz Biotechnology) and a rabbit polyclonal antibody against full-length ANGPTL4 from Abcam, Cambridge, UK. All of these antibodies were used at a dilution of 1:3000. For detection we used the ECL detection system (GE Healthcare).

\section{Metabolite assessments and plasma lipid profiles}

For rats, NEFA-HR (WAKO Chemicals, Germany) was used for measurements of plasma NEFA. Plasma insulin was measured using coated plates from Mercodia, Sweden. Trig/GB (Roche Diagnostics, Germany) was used for TG measurements. One Touch Ultra (Life Scan, Milpitas, CA) glucose sticks were used for blood glucose determinations on whole blood immediately after collection.

For mice, plasma cholesterol was determined using the Cholesterol PAP SL kit from Elitech (Sopachem, Ochten, Netherlands). Plasma triglycerides were determined using the GPO PAP kit from Instruchemie (Delfzijl, Netherlands). Plasma lipoproteins were separated using fast protein liquid chromatography (FPLC). For this $0.2 \mathrm{ml}$ of pooled plasma was injected into a Superose 6B 10/300 column (GE Healthcare Bio-Sciences AB, Roosendaal, Netherlands) and eluted at a constant flow of $0.5 \mathrm{ml} /$ minute with phosphate buffered saline ( $\mathrm{pH}$ 7.4). The effluent was collected in $0.5 \mathrm{ml}$ fractions and TG and cholesterol levels were determined.

\section{Statistical analysis}

Data are presented as mean \pm SEM. Statistical analyses were performed using unpaired $t$-test of variances or 
one-way ANOVA, where $*=p<0.05,{ }^{* * *}=p<0.01$ and ***: $=p<0.001$. Unless otherwise stated, comparisons were made to time $=0 \mathrm{~min}$ or to matched controls.

\section{Abbreviations}

ANGPTL: Angiopoietin-like protein; ActD: ActinomycinD; CHX: Cycloheximide; GPIHBP1: Glycosylphosphatidylinositol-anchored high density lipoproteinbinding protein 1; LPL: Lipoprotein lipase; NEFA: Non-esterified fatty acids also called free fatty acids FFA; PPAR: Peroxisome proliferator activated receptor.

\section{Authors' contributions}

$\mathrm{OK}, \mathrm{GO}$, and TO did the conception and design of the research and conducted most of the animal experiments. OK performed most of the analytical work. VS, GO, and TO had conducted preliminary experiments on which the study was designed. EV and SKN contributed to mRNA analyses and to design and performance of the gene array study, respectively, together with OK. RS, FM, and SK conducted the experiments on Angptl-/mice and most of the analyses on these animals. All authors contributed to analyses of data and to interpretation of the results. OK, GO and TO prepared the figures. GO and TO drafted the manuscript. All authors contributed to edition and revision of the manuscript. KS, GO, and TO approved the final version

\section{Acknowledgements}

This work was supported by the Research Council Medicine (project 12203), the Swedish Heart and Lung Foundation and the Kempe Research Foundations. We thank Dr. Anja Köster from Eli Lilly \& Company, Indianapolis for the gift of Angpt/ $4^{-/-}$mice and we thank Solveig Nilsson, Department of Medical Biosciences, Umeå University, for technical assistance and Nina Gennebäck, Department of Public Health and Clinical Medicine, Umeå University, for help with analyses of gene expression arrays.

\section{Author details}

'Department of Medical Biosciences/Physiological Chemistry, Umeå University, Umeå SE-90187, Sweden. ${ }^{2}$ Nutrition, Metabolism and Genomics group, Division of Human Nutrition, Wageningen University, Wageningen $6700 \mathrm{EV}$, The Netherlands. ${ }^{3}$ Present address: Department of Medicine, University of Gothenburg, Gothenburg SE-405 30, Sweden.

Received: 4 April 2012 Accepted: 9 November 2012

Published: 23 November 2012

\section{References}

1. Olivecrona T, Olivecrona G: The ins and outs of adipose tissue. In Cellular lipid metabolism. Edited by Ehnholm C. Heidelberg: Springer; 2009:315-369.

2. Wang H, Eckel RH: Lipoprotein lipase: from gene to obesity. Am J Physiol Endocrinol Metab 2009, 297(2):E271-E288.

3. Semb H, Olivecrona T: Two different mechanisms are involved in nutritional regulation of lipoprotein lipase in guinea-pig adipose tissue. Biochem J 1989, 262(2):505-511.

4. Bergo M, Olivecrona G, Olivecrona T: Forms of lipoprotein lipase in rat tissues: in adipose tissue the proportion of inactive lipase increases on fasting. Biochem J 1996, 313(Pt 3):893-898.

5. Bergo $M, W u G$, Ruge T, Olivecrona T: Down-regulation of adipose tissue lipoprotein lipase during fasting requires that a gene, separate from the lipase gene, is switched on. J Biol Chem 2002, 277(14):11927-11932.

6. Kersten S, Mandard S, Tan NS, Escher P, Metzger D, Chambon P, Gonzalez FJ, Desvergne B, Wahli W: Characterization of the fasting-induced adipose factor FIAF, a novel peroxisome proliferator-activated receptor target gene. J Biol Chem 2000, 275(37):28488-28493.

7. Yoshida K, Shimizugawa T, Ono M, Furukawa H: Angiopoietin-like protein 4 is a potent hyperlipidemia-inducing factor in mice and inhibitor of lipoprotein lipase. J Lipid Res 2002, 43(11):1770-1772.

8. Sukonina V, Lookene A, Olivecrona T, Olivecrona G: Angiopoietin-like protein 4 converts lipoprotein lipase to inactive monomers and modulates lipase activity in adipose tissue. Proc Natl Acad Sci USA 2006, 103(46):17450-17455

9. Yau MH, Wang Y, Lam KS, Zhang J, Wu D, Xu A: A highly conserved motif within the NH2-terminal coiled-coil domain of angiopoietin-like protein
4 confers its inhibitory effects on lipoprotein lipase by disrupting the enzyme dimerization. J Biol Chem 2009, 284(18):11942-11952.

10. Koster A, Chao YB, Mosior M, Ford A, Gonzalez-DeWhitt PA, Hale JE, Li D, Qiu Y, Fraser CC, Yang DD, et al: Transgenic angiopoietin-like (angptl)4 overexpression and targeted disruption of angpt|4 and angpt|3: regulation of triglyceride metabolism. Endocrinology 2005, 146(11):4943-4950.

11. Lichtenstein L, Mattijssen F, de Wit NJ, Georgiadi A, Hooiveld GJ, van der Meer R, He Y, Qi L, Koster A, Tamsma JT, et al: Angpt/4 protects against severe proinflammatory effects of saturated fat by inhibiting fatty acid uptake into mesenteric lymph node macrophages. Cell Metab 2010, 12(6):580-592.

12. Yin W, Romeo S, Chang S, Grishin NV, Hobbs HH, Cohen JC: Genetic variation in ANGPTL4 provides insights into protein processing and function. $J$ Biol Chem 2009, 284(19):13213-13222.

13. Mandard S, Zandbergen F, van Straten E, Wahli W, Kuipers F, Muller M, Kersten S: The fasting-induced adipose factor/angiopoietin-like protein 4 is physically associated with lipoproteins and governs plasma lipid levels and adiposity. J Biol Chem 2006, 281(2):934-944.

14. Lei X, Shi F, Basu D, Huq A, Routhier S, Day R, Jin W: Proteolytic processing of angiopoietin-like protein 4 by proprotein convertases modulates its inhibitory effects on lipoprotein lipase activity. J Biol Chem 2011, 286 (18):15747-15756

15. Hato $T$, Tabata M, Oike Y: The role of angiopoietin-like proteins in angiogenesis and metabolism. Trends Cardiovasc Med 2008, 18(1):6-14.

16. Young SG, Davies BS, Voss CV, Gin P, Weinstein MM, Tontonoz P, Reue K, Bensadoun A, Fong LG, Beigneux AP: GPIHBP1, an endothelial cell transporter for lipoprotein lipase. J Lipid Res 2011, 52(11):1869-1884.

17. Davies BS, Beigneux AP, Barnes RH 2nd, Tu Y, Gin P, Weinstein MM, Nobumori C, Nyren R, Goldberg I, Olivecrona G, et al: GPIHBP1 is responsible for the entry of lipoprotein lipase into capillaries. Cell Metab 2010, 12(1):42-52.

18. Davies BS, Waki H, Beigneux AP, Farber E, Weinstein MM, Wilpitz DC, Tai $L$, Evans RM, Fong LG, Tontonoz P, et al: The expression of GPIHBP1, an endothelial cell binding site for lipoprotein lipase and chylomicrons, is induced by peroxisome proliferator-activated receptor-gamma. Mol Endocrinol 2008, 22(11):2496-2504.

19. Doolittle MH, Ehrhardt N, Peterfy M: Lipase maturation factor 1: structure and role in lipase folding and assembly. Curr Opin Lipidol 2010, 21(3):198-203.

20. Peterfy M: Lipase maturation factor 1: A lipase chaperone involved in lipid metabolism. Biochim Biophys Acta 2012, 1821(5):790-794.

21. Gimble JM, Floyd ZE: Fat circadian biology. J Appl Physiol 2009, 107(5):1629-1637.

22. Olivecrona T, Chernick SS, Bengtsson-Olivecrona G, Garrison M, Scow RO: Synthesis and secretion of lipoprotein lipase in 3 T3-L1 adipocytes. Demonstration of inactive forms of lipase in cells. J Biol Chem 1987, 262 (22):10748-10759.

23. Wu G, Olivecrona G, Olivecrona $\mathrm{T}$ : The distribution of lipoprotein lipase in rat adipose tissue. Changes with nutritional state engage the extracellular enzyme. J Biol Chem 2003, 278(14):11925-11930.

24. Bergo M, Olivecrona G, Olivecrona T: Diurnal rhythms and effects of fasting and refeeding on rat adipose tissue lipoprotein lipase. Am J Physiol 1996, 271(6 Pt 1):E1092-E1097.

25. Gray NE, Lam LN, Yang K, Zhou AY, Koliwad S, Wang JC: Angiopoietin-like 4 (Angpt/4) protein is a physiological mediator of intracellular lipolysis in murine adipocytes. J Biol Chem 2012, 287(11):8444-8456.

26. Harndahl L, Wierup N, Enerback S, Mulder H, Manganiello VC, Sundler F, Degerman E, Ahren B, Holst LS: Beta-cell-targeted overexpression of phosphodiesterase $3 B$ in mice causes impaired insulin secretion, glucose intolerance, and deranged islet morphology. J Biol Chem 2004, 279 (15):15214-15222.

27. Bergo M, Olivecrona G, Olivecrona T: Regulation of adipose tissue lipoprotein lipase in young and old rats. Int J Obes Relat Metab Disord 1997, 21(11):980-986.

28. Ranganathan G, Pokrovskaya I, Ranganathan S, Kern PA: Role of A kinase anchor proteins in the tissue-specific regulation of lipoprotein lipase. Mol Endocrinol 2005, 19(10):2527-2534.

29. Forcheron F, Basset A, Del Carmine P, Beylot M: Lipase maturation factor 1: its expression in Zucker diabetic rats, and effects of metformin and fenofibrate. Diabetes Metab 2009, 35(6):452-457.

30. Schwanhausser B, Busse D, Li N, Dittmar G, Schuchhardt J, Wolf J, Chen W, Selbach M: Global quantification of mammalian gene expression control. Nature 2011, 473(7347):337-342. 
31. Zhang L, Lookene A, Wu G, Olivecrona G: Calcium triggers folding of lipoprotein lipase into active dimers. J Biol Chem 2005, 280(52):42580-42591.

32. Zhang L, Wu G, Tate CG, Lookene A, Olivecrona G: Calreticulin promotes folding/dimerization of human lipoprotein lipase expressed in insect cells (sf21). J Biol Chem 2003, 278(31):29344-29351.

33. De Gasquet P, Griglio S, Pequignot-Planche E, Malewiak Ml: Diurnal changes in plasma and liver lipids and lipoprotein lipase activity in heart and adipose tissue in rats fed a high and low fat diet. J Nutr 1977, 107(2):199-212.

34. Goubern M, Portet R: Circadian rhythm and hormonal sensitivity of lipoprotein lipase activity in cold acclimated rats. Horm Metab Res 1981, 13(2):73-77.

35. Sugden MC, Holness MJ, Howard RM: Changes in lipoprotein lipase activities in adipose tissue, heart and skeletal muscle during continuous or interrupted feeding. Biochem J 1993, 292(Pt 1):113-119.

36. Benavides A, Siches M, Llobera M: Circadian rhythms of lipoprotein lipase and hepatic lipase activities in intermediate metabolism of adult rat. Am J Physiol 1998, 275(3 Pt 2):R811-R817.

37. Tsutsumi K, Inoue Y, Kondo Y: The relationship between lipoprotein lipase activity and respiratory quotient of rats in circadian rhythms. Biol Pharm Bull 2002, 25(10):1360-1363.

38. Ruge $T$, Bergo $M$, Hultin $M$, Olivecrona $G$, Olivecrona T: Nutritional regulation of binding sites for lipoprotein lipase in rat heart. Am J Physiol Endocrinol Metab 2000, 278(2):E211-E218.

39. Arasaradnam MP, Morgan L, Wright J, Gama R: Diurnal variation in lipoprotein lipase activity. Ann Clin Biochem 2002, 39(Pt 2):136-139.

40. Parkin SM, Walker K, Ashby P, Robinson DS: Effects of glucose and insulin on the activation of lipoprotin lipase and on protein-synthesis in rat adipose tissue. Biochem J 1980, 188(1):193-199.

41. Wu G, Zhang L, Gupta J, Olivecrona G, Olivecrona T: A transcriptiondependent mechanism, akin to that in adipose tissue, modulates lipoprotein lipase activity in rat heart. Am J Physiol Endocrinol Metab 2007, 293(4):E908-E915.

42. Ruge T, Svensson A, Eriksson JW, Olivecrona T, Olivecrona G: Food deprivation increases post-heparin lipoprotein lipase activity in humans. Eur J Clin Invest 2001, 31(12):1040-1047.

43. Makoveichuk E, Sukonina V, Kroupa O, Thulin P, Ehrenborg E, Olivecrona T, Olivecrona G: Inactivation of lipoprotein lipase occurs on the surface of THP-1 macrophages where oligomers of angiopoietin-like protein 4 are formed. Biochem Biophys Res Commun 2012, 425(2):138-143.

44. Lookene A, Chevreuil O, Ostergaard P, Olivecrona G: Interaction of lipoprotein lipase with heparin fragments and with heparan sulfate: stoichiometry, stabilization, and kinetics. Biochemistry 1996, 35(37):12155-12163.

45. Sonnenburg WK, Yu D, Lee EC, Xiong W, Gololobov G, Key B, Gay J, Wilganowski N, Hu Y, Zhao S, et al: GPIHBP1 stabilizes lipoprotein lipase and prevents its inhibition by angiopoietin-like 3 and angiopoietin-like 4. J Lipid Res 2009, 50(12):2421-2429.

46. Davies BS, Goulbourne CN, Barnes RH 2nd, Turlo KA, Gin P, Vaughan S, Vaux DJ, Bensadoun A, Beigneux A, Fong LG, Young SG: Assessing mechanisms of GPIHBP1 and lipoprotein lipase movement across endothelial cells. J Lipid Res 2012, 53(12):2690-2697.

47. Martin B, Ji S, Maudsley S, Mattson MP: "Control" laboratory rodents are metabolically morbid: why it matters. Proc Natl Acad Sci USA 2010, 107 (14):6127-6133.

48. Mizutani N, Ozaki N, Seino Y, Fukami A, Sakamoto E, Fukuyama T, Sugimura Y, Nagasaki H, Arima H, Oiso Y: Reduction of insulin signaling upregulates angiopoietin-like protein 4 through elevated free fatty acids in diabetic mice. Exp Clin Endocrinol Diabetes 2012, 120(3):139-144

49. Yamada T, Ozaki N, Kato Y, Miura Y, Oiso Y: Insulin downregulates angiopoietin-like protein 4 mRNA in 3 T3-L1 adipocytes. Biochem Biophys Res Commun 2006, 347(4):1138-1144.

50. Gonzalez-Muniesa P, de Oliveira C, de Perez HF, Thompson MP, Trayhurn P. Fatty acids and hypoxia stimulate the expression and secretion of the adipokine ANGPTL4 (angiopoietin-like protein 4/ fasting-induced adipose factor) by human adipocytes. J Nutrigenet Nutrigenomics 2011, 4(3):146-153.

doi:10.1186/1472-6793-12-13

Cite this article as: Kroupa et al:: Linking nutritional regulation of Angpt/4, Gpihbp1, and Lmf1 to lipoprotein lipase activity in rodent adipose tissue. BMC Physiology 2012 12:13.

\section{Submit your next manuscript to BioMed Central and take full advantage of:}

- Convenient online submission

- Thorough peer review

- No space constraints or color figure charges

- Immediate publication on acceptance

- Inclusion in PubMed, CAS, Scopus and Google Scholar

- Research which is freely available for redistribution 